\title{
The Holy Communion and African rituals: An encounter between African religion and Christianity
}

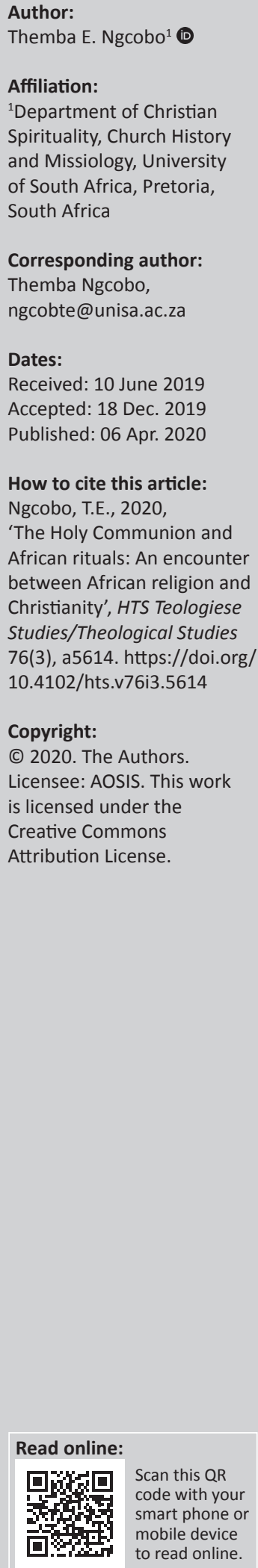

African lifestyle is informed, influenced and guided by African cosmology or cosmologies. These cosmologies (especially from the AmaZulu tribes, who are the focus of this study) shape social norms that are drawn from and explained by various indigenous knowledge systems that view the cosmology as intertwined. Consequently, according to this view, the spiritual world is not necessarily divorced from the physical world. This configuration of rationality could be observed during traditional and cultural gatherings in which myth is not only orally narrated but re-lived through rituals. In such cases, rituals provide a sphere where both the human world and the spiritual world converge in sharing a mythic experience represented in meals, drinks, songs, clapping of hands and dances. This convergence of God, amadlozi or badimo (generally translated as 'ancestors' or 'predecessors') brings the lived experience of the previous generation to reality. Therefore, the main argument in this contribution would be that the story of Jesus could still be re-lived through its most significant rituals such as the Holy Communion. This article reflects on the ritual of Holy Communion, which more emphatically addresses African cosmological views. The question of exclusivism of participation in this ritual is addressed to probe their individualistic pattern, which is perhaps more Western than African.

Keywords: Africanisation; myth and mythology; Ubuntu; African religion; Christianity; rituals.

\section{Introduction}

Through all the life stages, Africans, who are raised within African religious patterns and customs, are groomed through particular rituals to achieve a concrete and vibrant relationship with the (spiritual) world of amadlozi [the ancestors] as much as the (physical) world of the living. They believe that there is no distance between the deceased (or the living-dead) and the living in terms of time and space (Nurnburger 2007:37), and that occupation and moments are shared between the living and the amadlozi. However, this understanding of their worldview is also shared by Christianity, where, through rituals, Christians connect in fellowship with others, as well as the transcendent, especially during the Holy Communion. Both Africans and Christians view rituals as an expression of fellowship of the transcendent and human beings, for Christ said, 'Where two or three gather in my name, I will be there with them' (Mt 18:20).

Africans and Christians would then at least agree that a relationship between an individual and the transcendent is established even before birth. On the one hand, Africans believe that this relationship could be traced from conception until death, as individuals within African Traditional Religion (ATR) are engaged in active maintenance of close contact with the spiritual world, that is, the world of their ancestors and the Creator (Mndende 2005:19); on the other hand, Christians also believe that God knows individuals, even before they were conceived, and he knitted them into being in their mothers' wombs (Jr 1:5; Ps 139:13 \&14). God and amadlozi are, therefore, believed to be actively involved in an individual's life unto eternity, but so is the community.

Families, neighbours, the community and amadlozi form an important part of an individual's life. Both physical and spiritual worlds reflect the collective cosmological views that inform community (clan or tribal) norms and taboos that are socially accepted as the ultimate truth. As a result, an individual would be expected to seek to maintain a solid relationship and communication with these two worlds in both words and actions (e.g. rituals, fellowship and participation). AmaZulu [as one of the African tribes] treat religious unity or uniformity with the utmost respect (Phiri 2005:29). Therefore, anything that may bring about separation or dispute amongst the family or the community is a taboo. 
However, when it comes to the celebration of Holy Communion in most Christian denominations, exclusivity is emphasised. Perhaps, this interpretation is drawn from the first letter of Paul to the Corinthians, chapter 11, especially verse 27-29. Here, Paul warns the young Corinthian church to not misuse Holy Communion as an opportunity to become drunk (or carouse); instead, he emphasises that they should examine themselves before participation as to whether their actions reflect Christ. As a result, most churches have adopted Holy Communion as a meal of the sacred (and baptised) or a meal restricted to the baptised (Patte 2010:262; Von Allmen 1969:61). Only particular individuals in the Church would partake, and the rest of the (unbelieving) community is excluded. In doing this, how does the Church proclaim the Lord's death until he comes to the unbelieving world (1 Cor 11:26)?

The research reflects missiologically on the sacrament of Holy Communion as a means of not just re-telling the story of Jesus but of re-living it as well (Von Allmen 1969). It sought to engage with (1) the Biblical text, rather than the Western world, on how to understand this ritual, and (2) African cosmology (AmaZulu in this case) for Africanisation purposes. In this manner, the Holy Communion, as a Christian ritual, would be more relevant and meaningful to the AmaZulu and other Africans. This research also sought to focus on the omnipresent Lord, 'in Christ' and 'with Christ', whom the participants in the communion ritual are celebrating. Thus, the AmaZulu, who are partaking in the communion, would identify themselves with Christ, who is present in his own meal of commemoration, as amadlozi are believed to be present in rituals.

Moreover, with this conception of communion, the Holy Communion would cease to be a static and emotionless ritual, but be a communal celebration. This may help church rituals to be more appealing to the African worldview.

In the following sections, this research explores how African missiology can learn from African cosmology. Therefore, the following are described: (1) African (specifically, AmaZulu) rituals, (2) the Biblical discourses of Holy Communion as a Christian ritual and (3) encounterology between these two religions as a way of an Africanised Holy Communion. This is pursued through a qualitative methodology, which tends to focus on how individuals or groups of people can have different ways of looking at reality, and how they interpret and make sense of their experiences to understand these realities (Hancock, Ockleford \& Windridge 2007; Mohajan 2018). As a result, this research looks at how Africans view life in general and how they understand rituals specifically. However, as African views provide a broader scope, this research zooms-in on the AmaZulu tribe as a point of reference. The main reason for this is that the AmaZulu are part of the Southern African people, and most tribes and clans from this region share cosmological views. Thus, the AmaZulu do not exclusively own these views because these are vastly shared views.

\section{African rituals}

According to the AmaZulu, a ritual is one which unites more than the residents of the same world. Nurnberger (2007:38) observed that even the relations amongst the living ones are, to a large extent, 'ritualised', as a ritual itself is a vehicle of ancestral 'presence'. A ritual is, therefore, a medium that connects the dwellers of at least two worlds, the spiritual one of the amadlozi [the living-dead] and the physical one (of the living) as a way to communicate. Here, communication is not only understood simply in verbal speech but also in active participation and enactments (or re-living) through rituals. In such experiences, rituals provide a sphere where both the human world and the world of amadlozi converge in sharing a mythic experience during meals, drinks, songs, clapping of hands and dance. Spiritual beings are believed to have a direct involvement with participants in all proceedings, namely, eating, drinking and gratification.

During these rituals, the story (or myth ${ }^{1}$ ) is not only narrated but also enacted, as a reflection of indigenous knowledge systems (Ngcobo \& Beyers 2013). This is so, not only because a myth and a ritual cannot exist apart from each other (Segal 1999:37) but also because this seems to be the only possible systems to practically unite these two worlds. A myth and a ritual cohere in the transmission of this particular cosmology to the next generation through oral tradition and social engagements (or ceremonies). This does not usually happen in the 'classroom' setup, as found in Western education, but only in personal and communal engagements as they participate in rituals. Collaboration of myths and rituals provides a lived experience in the act of re-living a myth to an extent that believers are connected with the sacred. Such a connection is important for participants, because the re-living of a myth, through rituals, establishes and preserves their world (Lenssen 1980:21). Through the process of re-living, relationships are repaired, as families and relatives bond together. This promotes social security as the whole community is benefitted.

Through rituals, a myth (or traditional story) is kept alive, whereas, in myths, a ritual remains meaningful and relevant. In AmaZulu traditionalist societies, social life, as a whole, is ritualised to a substantial extent (Nurnberger 2007:38). Consequently, rituals are performed throughout the life stages of an individual. At birth, the AmaZulu are introduced to amadlozi through the ritual of imbeleko; ${ }^{2}$ at young adulthood, amadlozi are recognised through the ritual of umemulo; in marriage, amadlozi are included through the ritual of umbondo; in death, amadlozi are recognised through the

1.According to Ngcobo and Beyers (2013), Mythos were stories narrated orally before they were written down. They were passed on from one generation to the next orally, in spoken words. Therefore, a more justified way of defining a myth must be closely associated with speech, because the word mythos normally meant a word, or speech or blueprint in the early Greek language. Mythos was used to denote narrations addressed to people or the nation.

2.Imbeleko is a ritual performed to introduce children of the family to their amadlozi.

3.Umemulo is a ceremony of thanksgiving to amadlozi to celebrate the life of a well-behaved daughter.

4.A ceremony to introduce umakoti [the bride] to the family amadlozi and giving her a right to be a full member of the family. 
ritual of ukuphelezela ${ }^{5}$ and even in post-death, the ritual of ummbuyiso ${ }^{6}$ is performed. As a result, Mashau and Ngcobo (2016) added the following:

As a result, Africans perform different rituals at different occasions, e.g. at the birth of a child, the giving of names, circumcision and other initiation ceremonies, marriage, funerals, harvest festivals, praying for rain and many others. (p. 37)

Individuals are groomed through social contacts with lineal relatives and clan members. This provides a sense of belonging, identity and meaning of life. Communal participation is promoted to achieve the highest social uniformity; hence, the idiom, ayikho inkomo edla yodwa [there is no cow that grazes alone]. The whole community is invited to this celebration to eat, drink and be merry, as families engage with their ancestors (Gurganious 2010).

This is performed through specific symbolic objects or in a language that speaks mostly to a believer. These symbols ${ }^{7}$ are valued, as they have more than a literal meaning. Their function and meaning differ from one context to another, but what is common is that they (more often than not) point beyond themselves. Allen (2002:15) pointed out that symbols point to something transcendent, supernatural and trans-historical. Symbols (or allegories) are, therefore, mediums for revelation. They are either reserved as a representation or presentation of the sacred; for instance, when rain or mist falls after a slaughter, it is believed that amadlozi are pleased and have embraced the ceremony. Lenssen (1980) added the following:

The events and activities of the primordial past are [therefore] re-lived, where their ontological power is restored. The mythic world is a lived, sacred world, [that is] continuously or periodically accessible. (p. 28)

To a traditionalist or a myth-believer, myths illustrate their worldview, rituals open doors to re-living such a world and symbols act as guide-pointers. Every time participants partake in religious rituals and sacrifices in worship, the sacred time is translated to the present, as they share in it. A myth then becomes something that is lived and experienced. The believer is able to re-enact, re-live and witness the prehistoric events, for 'ritual action is the re-telling, re-acting, re-living of the time of the primordial events' (Lenssen 1980:26). Rituals provide for the recovery of this sacred time through repeated and periodical participation in that time. As a result, a ritual unites the two worlds and the dwellers of the same world, for 'there is no distance between the most proximate of the deceased and the living in terms of time and space' (Nurnburger 2007:37).

5.In this ritual, an ox would be slaughtered, and its skin will be buried with the deceased as umphako [the food for the journey].

6.Kruger et al. (2005:45) stated: At a ritual known as the 'bringing home the spirit', all the family (or clan) members participate, but only the male elders officiate, and an ox is sacrificed ... The recently deceased's name is included in the praise list of ancestors at this time, and he is called upon to take his place among the protectors and defenders of his line.

7.These may be omens, bull horns on the hut roof, diaphragms at umsamu [the inside part of the hut facing the door], isiphandla [bracelets made of goat skins] or even a traditional beer.
The living and the living-dead share time and space, and this is evidenced in ritualistic gatherings. The meal is not simply of amadlozi but also with amadlozi. This brings us to the meaning of Holy Communion in this context.

\section{Holy Communion Background}

There can be no argument (at least for the Christian community) that disputes the institution of Holy Communion by Jesus the Christ, as evidenced in the gospels of Matthew, Luke and John (Mt 26, Lk 22, Jn 13). However, throughout the centuries, there have been many heated discussions on the understanding of it, even amongst Reformers (Leithart 2000:23). Martin Luther believed that the Holy Communion is a presentation of Christ's body, whilst John Calvin believed that the sacrament is only a representation (see Botica 2010).

Nevertheless, the Universal Church agrees that the Holy Communion is a Christian ritual, as the church received a command from Christ, 'do this' (Lk 22:19). Moreover, the Bible is explicit enough to suggest that this practice was carried out by an Early Church in its liturgy (1 Cor 10:21; 11:17-34). It is of true significance that the Holy Communion has been celebrated throughout the centuries and has preserved the lives or at least the faith of many.

As mentioned above, Jesus is the founder of Holy Communion, and it cannot be understood away from the life of Jesus. Thus, it is important to note that food eating and sharing was very important in the whole ministry of Jesus, in his teachings as well as in practice (e.g. Jn 2:1-11; 12:2, Mt 9:10, 11; 22:2-14, Lk 7:36-50; 10:40; 11:37-42; 15ff. 19:6 and other passages). He declared himself as the living-bread, the bread of life (Jn 6) and water of life (Jn 7). He shared food and drink with his disciples and the mass before and after his resurrection (Ac 10:41), both privately and publicly. However, in those days, with whom you ate was as important as what you ate and how you ate. As eating was an act of fellowship and acceptance, it was understood that to eat with sinners was to accept them as friends and companions (Vander Zee 2004:141). It comes as no surprise that the Pharisees and other leaders had a serious problem when they would find Jesus sharing meals with sinners and commoners. However, Jesus would reflect on these meals and associations as missiological components (Lk 15).

Moreover, 'we cannot begin to understand the meaning of the Lord's Supper without reckoning with the fact that, before everything else, it is a Jewish meal' (Vander Zee 2004:140). The bread and wine were Jewish essential food. The bread 'was the all-important commodity of the ancient Near East (...) $[I t]$ was used for food in general' (Wood 1996:145, 146). It was made of wheat, the 'staff of life', for bread was a daily food and was referred to as a symbol of hospitality in Genesis 18:6 and Psalm 41:9; an understanding of covenantal fidelity in Leviticus 24:4; and as a sign of unity in 1 Corinthians 10:16-17 (Patte 2010:149). Wine was as important as bread, as 
it was regarded as a good gesture (Jn 2:1-11) and a sign of healing (reconciliatory offer) (1 Tm 5:23).

Furthermore, it is important to note that Biblically, the Holy Communion is linked to the Passover feast. This claim finds support in the Synoptic Gospels of Mark 14:1-2, 12-16 and John 13:21-30 (Wood 1996:696). Therefore, the Passover was a typology of Christ, as it pointed to Christ as a redemptive lamb (Jn 1:29 and 1 Cor 5:7). However, the Holy Communion is not a Passover meal in itself (Beckwith 1972:30). The Passover pointed to the coming Messiah, and the Holy Communion points back to Christ's earthly ministry as well as his second coming.

\section{What is Holy Communion?}

The Holy Communion 'is not an object, it is a way of life' (Von Allmen 1969:20). The term itself is not found anywhere in the Bible, but its usage is identical to other Biblical passages. The adaptation of the term could be traced back to the Bible. To begin with, the word 'communion' is derived from a Greek word koinonia, referred to in 1 Corinthians 10:16-17 as 'fellowship', 'friendship' or 'participation' in the body and blood of Christ by sharing the bread and the cup of blessing (Patte 2010:262). As a participatory experience, communion also means 'communication', 'contribution' and 'in common', in the sense of the Latin word communis, with its Greek root koin, referring to sharing something with someone (Wood 1996:217). 'The koin-word group is translated as fellowship, sharing, partnership, participation and communion' (Breed \& Semenya 2015:70).

Communion could also be understood by another Greek word ynaxis, which means 'union' or 'community gathering' (Welker 2000:3). Koinonia and ynaxis epitomised the lifestyle of early church (especially in the Book of Acts).

In fellowship, the instructions of Holy Communion were given by Christ as he shared bread and wine with his disciples. The words, 'this is my body' followed by 'this is my blood ... which is poured out for many for the forgiveness of sins' (Mt 26:26 \& 28), imply the inclusive purpose of his death. This is far from being an individualistic approach. Von Allmen (1969) argued that the Holy Communion:

[S]hould be the final test of peace and unity in the church or, to express it negatively, that it is over the celebration and interpretation of the Supper that dogmatic and canonical divisions are most evident. (p. 9)

It should reflect that the blood of Christ was shed for the many, that is, for everyone or anyone. In this manner, the Holy Communion brings about an encounter amongst humanities and between humanity and Christ.

However, the Holy Communion or Lord's supper (as some call it) is not only about here and now, it is also inherently eschatological or futuristic (Von Allmen 1969:9). Christ declared to his disciples (Mt 26):
I tell you, I will not drink from this fruit of the vine from now on until that day when I drink it new with you in my Father's kingdom. (v. 29)

Therefore, the Holy Communion looks forward to the second coming of Christ and the final establishment of the kingdom of God. It promotes and preaches the message of a great reunion, when the lord and his bride - the brethren, friends and relatives - meet (again) to eat and share at the lord's table, 'blessed are those who are invited to the wedding ceremony of the Lamb' (Rv 19:9).

\section{Basic understanding of Holy Communion today}

The common understanding of the Holy Communion is mostly on the application of commanding-invitation, 'Do

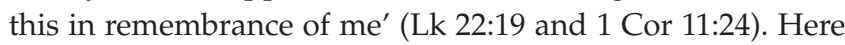
the church finds credentials to perform such a ritual, as she remembers Christ. This notion of remembrance is rooted in a Greek word anamnaysis, transliterated as 'anamnesis'. The word anamnesis finds its root in the Hebrew word zikazon, which relates to 'memory', 'memorial', 'celebration' or 'cultic commemoration' (Von Allmen 1969:23-24). It is a course of re-calling, remembering, recollecting, re-live-ing or even re-present-ing a past event (Dix 1945:245). This way of interpretation tends to deem the Holy Communion as a 'funereal Communion service' (Vander Zee 2004:136).

However, anamnesis is deeper than simply remembering past events. The re-presenting part of it refers to acting them out. It is all about remembrance in action and in participation. It is the ritual that recalls the past event (or story), seeking to restore its original virtue; therefore, it is much more than a mnemonic ceremony; it is re-present-ing, re-enacting or re-living the event in commemoration (Von Allmen 1969:24). Anamnesis provides a profound insight into the 'real presence' the experience of koinonia (fellowship or participation) with Christ in his, life, death, resurrection and anticipation of his second coming (Vander Zee 2004:136).

Anamnesis not only involves the past but also the present and the future of our redemption. It is the community coming alive.

However, in most cases, the Holy Communion is widely interpreted as a 'meal of the baptized' (Von Allmen 1969:61) or a meal restricted to the baptised (Patte 2010:262). It is more exclusive than inclusive. In some denominations, not everyone, who have been baptised are allowed to partake in the meal (communion), instead it is limited to those who are 'holier', for 'holy things [are] for the holy ones' (Leithart 2000:37).

What then makes Holy Communion 'holy'? Is it the bread and wine, which represent the body and blood of Christ? Or is it holy because 'hallowed' or 'consecrated' individuals eat together? Or is it holy because the holy Lord communes with imperfect beings, who, through the process, are sanctified? 
It is important to note that in the gospels and in the Letters of Paul, the words 'on the night He was betrayed, He took bread and wine' are continuously (and ritually) repeated (Mt 26:26; 1 Cor 11:23). As much as Jesus knew that Judas would betray him (Lk 22: 1-6), that Peter would deny him (Jn 18:15-27) and that Thomas would not believe in the resurrection (Jn 20:24-29), he was still willing to share this important meal with them, the sinners as they were, for betrayal is the shadow of love. Sinners were not exempted from that table. This is the true proclamation of his death until he comes. He died for all, more precisely, he died for sinners, not saints.

During Holy Communion, there is more emphasis on individualistic introspection, which is perhaps more a reflection of Western individualism than the Middle Eastern (Jewish) or African inclusivity. The Western understanding and implication would relate to individualistic application, without taking into consideration that the Letter of Paul was addressed to the whole congregation as a group, other than specific individuals. However, this is made to discredit those considered lessor in faith, and to disqualify children, because they are not fit enough to make a conscious decision. However, the all-inclusive Christ once declared: 'Let the little children come to me, and do not hinder them, for the kingdom of heaven belongs to such as these' (Mt 19:14). The Jewish Christ would not be as exclusive as the Western Christ. The Jewish one would know that religious education is achieved through participation.

Through sharing of the body and blood of Christ, the story of Jesus, the Jew, who connected God (the Transcendent One) with the community of sinners, here and now, is re-presented and re-lived. This is in line with Jewish and African rituals or ceremonies, where the ritual's focal point is never aimed at individualistic fulfilment only but at serving communal interests as well.

\section{An encounter between African rituals and Holy Communion}

\section{Ubuntu and communion}

The saying, 'sharing is caring', could be said to be relevant for both Africans and Christians. This sentiment is also reflected in the SeSotho idiom, bana ba motho ba arolelana thoho ya tsie [children of the same womb would share the head of a locust] and the isiZulu proverb, isisu somhambi singanso yenyoni [the stomach of a traveller is of the size of a bird's kidney]. Both proverbs seek to emphasise sharing, specifically that you do not have to have much for you to share. Ubuntu, as an African philosophy (see Ramose 2005), would therefore emphasise communion in meals rather than exclusion. Ramose (2005:37) defined Ubuntu as 'a humane, respectful and polite attitude towards others'. Breed and Semenya (2015:2) added that 'it should also be noted that this African philosophy of ubuntu is characterised by an interconnectedness between the dead, the living and the yet to be born'. This suggests that ubuntu serves for both ontological and metaphysical reasons. Furthermore, Koopman (2007) described Ubuntu as follows:

True humanity is not defined by independence and rationality, but by the willingness to enter into relationships with others... In the interaction with others, in the communion, in the relationship, I find my essence and being. I receive my being from the other. We receive our existence from the hands of the other and my existence is meaningful because there are others who want to share their existence with me. (p. 183)

Ubuntu relates well with the understanding and the importance of being, a human being, which is that 'human beings find their sense of being through being part of the community' (Ngcobo 2014:124). Christ himself understood this significant role of humanness. When his disciples asked Jesus to chase away the $\operatorname{crowd}^{8}$ (Mt 15:29-39), he was confronted with an ethical dilemma, and the principles he applied aligned with the principles of $u b u n t u$. In Africa, it is not only relatives and family that are invited to participate in a ritual or ceremony but the whole community is invited; even strangers are welcomed. This sharing of meals makes human relations stronger.

This is also true with Christ; Christ, as the bread of life, was always willing to share meals with others. He was open to share with both males and females, and adults and children. He did not discriminate. Christ, as the bread and the wine that was shared for all, he must be, therefore, the fulfiller for all.

\section{Rituals and myths}

Myths $^{9}$ are the forms of religious education in both Christianity and the African religion. In Exodus, a paschal or Passover ritual (which later formed the Christians' Holy Communion) was to be a means of introducing the young ones in a Jewish religion. God said, 'when your children ask you what a Passover is?'(Ex 12:27-28). This question would therefore open up for a re-telling of the myth of the Great Exodus from Egypt to the Promised Land. This may make the ritual of the Passover more relevant. The author of Exodus understands that this ritual on its own would eventually lose meaning; therefore, to sustain it, the myth or story must be told, repeatedly. The application of myth and ritual should not to be exercised without the addition of some edifying insight. Through active participation, children would seek to ask relevant questions on the necessity of such a ritual. Meaningful participation in rituals means that participants are involved in something of significant importance, which greatly affects their daily lives (Kruger 2018:2). As a result, through active participation, the myth would then make the ritual relevant and meaningful.

This understanding is the same as the African understanding of religious education. African religious education is not in

\footnotetext{
8.'Jesus called his disciples to him and said 'I have compassion for these people; they have already been with me three days and have nothing to eat. I do not want to send them away hungry, or they may collapse on the way' (Mt 15:32).
}

9.See footnote 1 for the definition. 
creeds, catechisms and chapels. It is transmitted through engagements and active participations. As a result, myths (or stories) that accompany rituals are repeatedly narrated as a means of education. Paul emphasises that, 'for whenever you eat this bread and drink this cup, you proclaim the Lord's death until He comes' (1 Cor 11:26). That is why the stories of incarnation, resurrection, ascension and Parousia are important during Holy Communion. Without re-telling his story, the ritual of Holy Communion becomes meaningless and irrelevant. The proclamation of his kingdom, until he comes (or religious education) cannot be probable without mythology and rituals. The Holy Communion would then remind Christians about Christ and what he did for them on the cross and provide them with courage to look forward to the second coming.

\section{Transcendental presence during rituals}

In both African and Christian religions, it is believed that there is an interconnection of two worlds (the spiritual world and the physical one). Christ promised his followers that when two or three gather in his name, he will be there with them (Mt 18:20). This worldview suggests that the spiritual world can easily intersect with the physical one; they share time and space.

This would resonate with the African belief of the presence of amadlozi during rituals, for in the African religion, it is understood that rituals are to be shared experiences between the living and the living-dead (Mashau \& Ngcobo 2016:36). This intersection of space and time could be fully experienced during rituals. During rituals, both worlds converge. During Holy Communion, by eating his body and drinking his blood, the transcendent is imparted in believers, whilst in African rituals, the relationship between both the worlds are renewed. Mndende (2005) argued as follows:

Rituals revive the relationships within the community and between the living and the ancestors. This also means reviving the relationship between the physical world (this world) and the spiritual world (the world after death). (p. 18)

Rituals always act as a link between human and supernatural beings, and, moreover, the presence of the transcendent tightens community bonds. Mashau and Ngcobo (2016) added:

[This] suggests that relationships play a vital role in the African worldview. They act as safeguards for both the clan and society. As long as there is peace, there is prosperity. These relations are measured by the unity and collaborations among the living and the interconnectedness of the living with the living dead (...) Rituals then act as a medium to bring these two worlds together, but also keep the physical world intact as their relationship is repaired. (p. 37)

Therefore, if God is believed to be all-inclusive, the Holy Communion ritual cannot be exclusive. It must unite God and people, and human beings with one another.

\section{The importance of commemorations}

Both Christ and amadlozi dare not to be forgotten; for to be forgotten means to seize to exist, for 'those who are not remembered after death have met their ultimate end' (Nyirongo 1997:72). As a result, Christ commanded Christians to do this (ritual) to commemorate him. He said, 'This is my body, which is for you; do this in remembrance of $\mathrm{me}^{\prime}$ (Lk 22:19; 1 Cor 11:24). Kruger (2018) emphasised:

It is evident that the concepts of meaning (cognition) and remembrance (recognition) are evident in this context [of the Holy Communion]. The assurance of the Holy Communion is that Christ wants to assure us, by this visible sign and pledge, that through the Holy Spirit's work, we share in His true body and blood as surely as our mouths receive these holy signs in His remembrance. (p. 7)

The remembrance of the transcendent has much to do with our own self-identity and assurances, for those who know their past (history), they know themselves. That is why, in Africa, izithakazelo [clan names] are made up of lineal names of amadlozi, for when amadlozi are remembered, they continue to maintain a place in the family [or clan] or tribe (see Kruger, Lubbe \& Steyn 2005:45). As a result, the more we commemorate Christ and amadlozi, the closer we become as people. Through this, we form a particular identity. Through this, there would be more peace in the world, as we share a collective human dignity (Ngcobo 2014:126).

\section{Conclusion}

The Holy Communion and African rituals have shared views on the importance of relationships amongst human beings and between humans and the transcendent. Christianity was never opposed to culture, rather could have learnt from it, for both Biblical worldview and African cosmology relate to the concept of spiritual and physical world, which are interconnected. African culture and religion are not estranged from Christianity but were set in opposition to Western epistemologies when Christianity came to Africa.

The Western culture (Western Christianity) has diluted the Biblical message of Christ. This brought about division and exclusion of individuals, cultures and races.

All religious phenomena should be contextually minded in their relevance and meaningfulness. In other words, it has to be mindful of the people, customs, history, environment and so forth, in which that religion finds itself. This is not contextualisation or simulation. The communication between the Bible and the African religion should be reciprocal, not one-sided. In this context, the intention of Holy Communion is twofold: It unites Christ and the church, and it unites Christians to one another (Von Allmen 1969:55). Its communication is both vertical and horizontal, and it does not only imply spiritual connections but also denounces communal bonds. 
The Holy Communion should be a meal, not just about a Jew named Jesus, who lived in the past, but with Jesus, for Christ has said, 'For where two or three gather in my name, there am I with them' (Mt 18:20).

Then the Lord's Supper would cease to be a 'supperwithout-the-Lord'; a static and dull event, but the Lord would be more in touch with all the happenings of his church. The supper will then be an actual communion with Christ and in Christ.

Anamnesis, as an African ritual, is not just about re-calling but also about participation, as we re-enact Christ's life. Instead of re-citing the history, we re-live his story. We re-live his life as he re-lives it through us, in us and with us. Since there is one loaf (the bread) and many of us, as we partake in it, we become one body in Christ.

\section{Acknowledgements Competing interests}

The author has declared that no competing interest exist.

\section{Author(s) contribution}

I declare that I am the sole author of this research articleEthical consideration

\section{Ethical considerations}

This article followed all ethical standards for a research without direct contact with human or animal subjects.

\section{Funding information}

This research received no specific grant from any funding agency of the public, commercial or not-for-profit sectors.

\section{Data availability statement}

Data sharing is not applicable to this article as no new data were created or analysed in this study.

\section{Disclaimer}

The views and opinions expressed in this article are those of the author and do not necessarily reflect the official policy or position of any affiliated agency of the author.

\section{References}

Allen, D., [1998] 2002, Myth and religion in Mircea Eliade, Routledge, New York.

Beckwith, R.T., 1972, The service of Holy Communion and its revision, Marcham Manor Press, Abingdon.

Breed, G. \& Semenya, K., 2015, 'Ubuntu, koinonia and diakonia, a way to reconciliation in South Africa?', HTS Teologiese Studies/Theological Studies 71(2), Art. \#2979, 9 p. https://doi.org/10.4102/ hts.v71i2.2979

Botica, D.A., 2010, 'The Eucharist in Theology of Martin Luther and John Calvin', in Simut CC 'Perischoresis: The Theological Journal of Emanuel University of Oradea, edn., 2, vol., 8, Emanuel University, Romania.

Gurganious, T., 2010, African religion, viewed 09 April 2014, from https://www. spiritualliving360.com/index.php/african-religion-8664/.

Hancock, B., Ockleford, E. \& Windridge, K., 2007, An introduction to qualitative research, viewed 27 November 2019, from https://www.rds-yh.nihr.ac.uk/wpcontent/uploads/2013/05/5_Introduction-to-qualitative-research-2009.pdf.

Koopman, N., 2007, 'Some theological and anthropological perspectives on human dignity and human Rights', in Scriptura, vol. 95, pp. 177-185, University of Stellenbosch, Cape Town.

Kruger, F.P., 2018, 'Participation in Christ's body and his blood during celebration of Holy Communion as illuminated by the meaningful lenses of cognition and recognition', HTS Teologiese Studies/Theological Studies 74(2), 4767. https://doi. org/10.4102/hts.v74i2.4767

Kruger, J.S., Lubbe, G.J.A. \& Steyn, H.C., 2005, The human search for meaning: $A$ multireligious introduction to the religions of humankind, VIA Afrika, Cape Town.

Leithart, P., 2000, Blessed are the Hungry: Meditation on the Lord's Supper, Canon Press, Moscow.

Lenssen, M.C., 1980, Myth and philosophy: The use of myth in the thought of Eliade, Schelling and Ricoeur, University Microfilms International, Ann Arbor, MI.

Mashau, D. \& Ngcobo, T.E., 2016, 'Christian mission in creative tension with African worldview(s): A post-colonial engagement regarding life after death and ancestry', Missionalia 44(1), 34-49. https://doi.org/10.7832/44-1-89

Mndende, N., 2005, 'Ancestors and healing in African religion: A South African religion', in I. Wulfhorst (ed.), Ancestors, spirits and healing in Africa and Asia: A challenge to the church, pp. 13-24, The Lutheran World Federation, Geneva.

Mohajan, H., 2018, Qualitative research methodology in social sciences and related subjects, viewed 27 November 2019, from https://mpra.ub.uni-muenchen. de/85654/1/MPRA_paper_85654.pdf.

Ngcobo, E.T. \& Beyers, J., 2013, 'Is it still possible to study religion religiously today? Mircea Eliade's religious apologetic account', Verbum et Ecclesia 34(1), Art. \#702, 8 p. https://doi.org/10.4102/ve.v34i1.702

Ngcobo, T.E., 2014, 'Homelessness and human dignity in the city of Tshwane: An encounter with personhood', Missionalia 42(1/2), 120-33. https://doi.org/ $10.7832 / 42-1-2-51$

Nurnburger, K., 2007, The living dead and the living God: Christ and the ancestors in a changing Africa, Cluster, Pietermaritzburg.

Nyirongo, L., 1997, The gods of Africa or the God of the Bible? The snares of African traditional religion in Biblical perspective, University of Potchefstroom, Potchefstroom.

Patte, D., 2010, 'Communion', in Cambridge Dictionary of Christianity, Cambridge University Press, Cambridge.

Phiri, I.A., 2005, 'Healing from the traumas of crimes in South Africa: Interaction of African religion with Christianity as perceived by African female traditiona healers', in I. Wulfhorst (ed.), Ancestors, spirits and healing in Africa and Asia: A challenge to the church, pp. 25-39, Lutheran World Federation, Geneva.

Ramose, M.B., 2005, African philosophy through Ubuntu, Mond Books, Harare

Segal, R.A., 1999, Theorizing about myth, University of Massachusetts Press, Amherst.

Vander Zee, L.J., 2004, Christ, baptism and the Lord's supper: Recovering the sacraments for Evangelical worship, InterVarsity Press, Downers Grove, Illinois.

Von Allmen, J.J., 1969, The Lord's supper: Ecumenical studies in worship, No. 19, Lutterworth Press, London.

Welker, M., 2000, What happens on holy communion?, William B. Eerdmans, Cambridge.

Wood, D.R.W., 1996, 'The Lord's supper', in I.H. Marshall, A.R. Millard \& J.I. Packer (eds.) New Bible dictionary, 3rd edn., pp. 696-699, InterVarsity Press, Downers Grove, IL. 